\title{
Sustaining Cocoa Production on Oxisols in Malaysia
}

\author{
Jusop Shamshuddin, Qurban Ali Panhwar, Ismail Roslan, Che Ishak Fauziah, \\ Umme Aminun Naher, and Khalid Rehman Hakeem
}

\begin{abstract}
Oxisols are dominated by variable charge minerals in their clay fraction, containing an insufficient amount of $\mathrm{Ca}$ and $\mathrm{Mg}$ in their soil solutions. Under natural conditions, cocoa grown on the soils is subjected to the stress of low $\mathrm{pH}$ and $\mathrm{Al}$ and/or Mn toxicity, which eventually produces low yields. This chapter discusses the chemical properties of Oxisols in Malaysia and explains how the productivity of the soils is enhanced using lime or basalt, which increases soil $\mathrm{pH}$. When the $\mathrm{pH}$ goes up above 5, $\mathrm{Al}$ in the soil solutions is precipitated as inert Al-hydroxides, with the concomitant elimination of toxic $\mathrm{Mn}$. The increase in $\mathrm{pH}$ would result in the increase of the CEC, attributed to the reaction of the variable charge minerals present in the soils. Basalt application would also lower $\mathrm{pH}$ of the soils, which further increases the CEC. On dissolution, lime supplies $\mathrm{Ca}$ and $\mathrm{Mg}$ into the soils, and basalt not only releases these metals, but also $\mathrm{K}, \mathrm{P}$, and $\mathrm{S}$. Ca, by itself, is able to reduce $\mathrm{Al}$ toxicity. One of the best methods of alleviating the infertility of Oxisols for cocoa cultivation is to apply basalt in combination with organic materials. Growing cocoa on Oxisols requires heavy application of NPK fertilizers, usually in the form of ammonium sulfate, rock phosphate, and muriate of potash, respectively. Occasionally, kieserite is applied to increase $\mathrm{Mg}$ reserve in the soils. Application of a high amount of $\mathrm{N}$ fertilizer will in the end acidify the soils, but it will be offset by the production of hydroxyl ions due to the specific adsorption of phosphate and sulfate ions on the surfaces of the oxides of Fe present in the soils. In that way, the production of cocoa on the Oxisols of Malaysia is sustained.
\end{abstract}

Keywords Amelioration • Application - Cultivation • Management • Mineral charge $\bullet$ Toxicity

\footnotetext{
J. Shamshuddin $(\varangle) \bullet$ Q.A. Panhwar $\bullet$ I. Roslan $\bullet$ C.I. Fauziah

Department of Land Management, Faculty of Agriculture, Universiti Putra Malaysia, 43400 Serdang, Selangor, Malaysia

e-mail: shamshud@upm.edu.my

U.A. Naher

Soil Science Division, Bangladesh Rice Research Institute, Gazipur 1701, Bangladesh

K.R. Hakeem

Faculty of Forestry, Universiti Putra Malaysia, 43400-Serdang,

Selangor, Malaysia
} 


\section{Introduction}

Cocoa (Theobroma cacao) is an important agricultural commodity in the export market of Southeast Asia and West Africa. In Malaysia, the crop was first planted in Jerangau, Terengganu (Peninsular Malaysia) in the 1950s and was later spread to Tawau, Sabah (East Malaysia). To support the continued growth of the cocoa industry in Malaysia, a research station with state-of-the-art facilities was set up by the government in Temerloh, Pahang. The three cocoa-planting areas have something in common: they have similar soil type which, according to soil taxonomy (Soil Survey Staff 2010) can be classified as Oxisols, considered to be among the most weathered soils in the tropics. However, the yield of cocoa planted in the soils in terms of its bean is reasonably high considering their low productivity. This is because of the proper soil/agronomic management practices being put into place during the course of cocoa production on the infertile soils.

Currently, the national average of cocoa production in Malaysia is about $0.8 \mathrm{t}$ ha $^{-1}$ year $^{-1}$ (Shamshuddin and Noordin 2011). This is far too low compared to those in African countries, such as the Ivory Coast. For Malaysia, the target rate of cocoa bean production is $1.5 \mathrm{tha}^{-1}$, which is still way below the potential yield of $10 \mathrm{tha}^{-1}$ year-1. However, in Tawau, Sabah, a yield of $>2 \mathrm{tha}^{-1}$ year $^{-1}$ is achievable following good soil management practices.

\section{Chemical Properties of Oxisols}

In order to know how and why cocoa is able to grow sustainably on Oxisols, we need to understand the chemical properties of the soils and their responses to the application of soil amendments and fertilizers. We know that Oxisols occurring in Malaysia are acidic in nature, with pHo ranging from 4.5 to 5.0 (Tessens and Shamshuddin 1983; Shamshuddin and Fauziah 2010a). They are also known to contain toxic amounts of $\mathrm{Al}$ and/or $\mathrm{Mn}$ in the soil solutions (Shamshuddin et al. 2011) that affect cocoa growth as well as its taste (Shamshuddin and Noordin 2011). Oxisols are defined by the presence of an oxic diagnostic horizon (Soil Survey Staff 2010). The soils are extremely weathered, dominated by the presence of kaolinite and sesquioxides in the clay fraction (Anda et al. 2008a; Shamshuddin and Anda 2008). Under natural conditions, the CEC of Oxisols is very low, with value $<16$ $\mathrm{cmol}_{\mathrm{c}} \mathrm{kg}^{-1}$ clay. As such, basic cations are mostly lost via leaching under the environment prevailing in the tropics, further lowering the productivity of the soils.

We know for sure that soil materials are both negatively and/or positively charged. The negative charge is derived via a process called isomorphic substitution. For instance, the replacement of $\mathrm{Si}$ by $\mathrm{Al}$ in mica present in soils would result in an excess of negative charges, termed negative permanent charges (Shamshuddin 2011, 2012). Positive permanent charges also exist in the soils, being produced by the isomorphic substitution of Fe by Ti in soils containing a high amount of oxides of Fe (Tessens and Zauyah 1982). 
$\mathrm{Fe}$ oxides have another kind of charge known as variable charge. As the $\mathrm{pH}$ of the ambient solution changes, the charge on the surfaces of these minerals also changes. When the $\mathrm{pH}$ is low, protons are chemisorbed onto the minerals to become net positively charged (Shamshuddin 2011, 2012). On the contrary, the minerals are net negatively charged at high $\mathrm{pH}$. The $\mathrm{pH}$ at which the net charge of the variablecharge mineral is zero is termed pHo (Van Ranst et al. 1998; Anda et al. 2008a).

The value of pHo for silicate is low (close to 4 or lower), whereas that of oxides is higher (mostly $>5$ ). Oxisols are composed of many variable-charged minerals, such as goethite and hematite. The pHo reported in the literature is actually the resultant pHo value for all the minerals in the soils. As oxides are abundant in Oxisols (Tessens and Shamshuddin 1983; Anda et al. 2008a; Shamshuddin and Fauziah 2010a), their pHo are high, with values 5 or higher.

In reality, the mineralogical composition of soils varies according to their stage of weathering. As the soils weather, more oxides are formed, leading to an increase in their pHo (Tessens and Shamshuddin 1983). It is expected that at the last stage of soil weathering, the soils become less productive and hence need special soil management practices to sustain cocoa production.

Basically, the total charge in the soils can be subdivided into permanent and variable charge components. The amount of total charge in the soils can be manipulated by changing their variable charge component. The variable negative charge (CEC) in the soils is related to the difference between $\mathrm{pHo}$ and $\mathrm{pH}(\mathrm{pHo}-\mathrm{pH})$ (Shamshuddin and Fauziah 2010a; Shamshuddin 2012). Hence, the CEC of the soils can be increased by increasing the difference between their $\mathrm{pHo}$ and $\mathrm{pH}$. This can be done either by lowering $\mathrm{pHo}$, increasing $\mathrm{pH}$, or both. The former can be done by incorporating basalt into the soils (Anda et al. 2009, 2013; Shamshuddin and Kapok 2010; Shamshuddin and Fauziah 2010b), whereas the latter is easily accomplished by lime application (Shamshuddin et al. 1991, 1998) or by applying basalt (Shamshuddin and Kapok 2010; Anda et al. 2013).

A soil system is stable when the charge in it is low, meaning that soil potential decreases as the charge decreases. Therefore, the potential in the soil is low when soil $\mathrm{pH}$ is near its $\mathrm{pHo}$. So, under natural conditions, soil $\mathrm{pH}$ tries to move to its $\mathrm{pHo}$ in order to achieve maximal stability. As soil $\mathrm{pH}$ increases with weathering, its $\mathrm{pHo}$ increases. This phenomenon has been shown clearly by the study of Tessens and Shamshuddin (1983). These researchers found that soil $\mathrm{pH}$ increased linearly with increasing pHo.

Primary minerals in soils disintegrate during the course of soil weathering and new minerals are formed thereafter, meaning that the silicates in the soil change to oxides of $\mathrm{Fe}$ and/or $\mathrm{Al}$, and consequently the pHo of the soils is increased. In the end, soil $\mathrm{pH}$ is increased in tandem with the $\mathrm{pHo}$ increase. This is why the $\mathrm{pH}$ of Oxisols is higher than that of the Ultisols as observed in the Malaysian study (Tessens and Shamshuddin 1983; Shamshuddin and Fauziah 2010a).

Tessens and Shamshuddin (1983) had analyzed the pH of many Oxisol samples from all over Peninsular Malaysia and found that the values were mostly in the range of 4.5 to 5.0. Under normal circumstances, soils will be at their greatest stability when the potential in them is zero, that is, at the $\mathrm{pH}=\mathrm{pHo}$; hence, the $\mathrm{pH}$ of the Oxisols tries to approach 4.5-5.0 in order to remain under stable condition. 
As the soil $\mathrm{pH}$ of highly weathered Oxisols is low $(<5)$, Al on their exchange complex is readily dissolved and goes into the soil solution. In many cases, the Al in the soil solution is present at toxic levels for crop growth (Shamshuddin et al. 1991, 1998). Naturally, Al concentration in the soil solution increases as the $\mathrm{pH}$ is lowered. Likewise, Mn may exist at toxic levels under low $\mathrm{pH}$ condition. Low soil solution $\mathrm{pH}$ and high $\mathrm{Al}$ concentration have little consequence on the growth of either oil palm or rubber, but they are expected to affect the growth and yield of cocoa significantly (Shamshuddin and Noordin 2011).

\section{Lime Application to Improve Soil Productivity for Growing Cocoa}

One of the most common agronomic practices to alleviate soil acidity is lime application, using ground magnesium limestone (GML). However, the ameliorative effects of GML are only observed in the zone of its application (Shamshuddin and Ismail 1995). When GML is added into an Oxisol, its $\mathrm{pH}$ increases with value depending on the rate applied. Because of the presence of variable-charged minerals in the soil, the CEC is consequently increased. Under this situation, the cations in the Oxisol are held by the negatively charged soil surfaces. This means that a GML application only helps alleviate the subsoil acidity. Therefore, a deep rooting crop such as cocoa still suffers from $\mathrm{Al}$ and/or toxicity (Shamshuddin et al. 1997). Shamshuddin and Ismail (1995) found that $\mathrm{Ca}$ and $\mathrm{Mg}$ in the topsoil could be partially brought to the subsoil by applying GML in combination with gypsum at the appropriate rate. When this agronomic practice is done and over with, the excess $\mathrm{Ca}$ from the dissolution of the gypsum present in the topsoil can subsequently move down the soil profile.

To grow cocoa on Oxisols, their $\mathrm{pH}$ needs to be raised to a value above 5. At this $\mathrm{pH}$ level, $\mathrm{Al}$ in the soil solution starts to precipitate as inert Al-hydroxides, rendering it unavailable to the growing cocoa in the field, with concomitant elimination of Mn. Soil solution $\mathrm{pH}$ can be increased effectively by GML application (Shamshuddin et al. 1991, 2009, 2010). For this reason, it is a standard practice to apply GML in the planting hole at least $4 \mathrm{t} \mathrm{ha}^{-1}$ (Rosilawati et al. 2014). According to MARDI (1990), $159 \mathrm{~kg}$ of GML should be applied in order to raise soil $\mathrm{pH}$ to the required level and subsequently eliminate $\mathrm{Al}$ and/Mn from the soil solution so that cocoa seedlings will not be under the stress of $\mathrm{H}^{+}, \mathrm{Al}^{3+}$, and/or $\mathrm{Mn}^{2+}$.

\section{Basalt Application to Improve Soil Productivity for Growing Cocoa}

Basalt is sporadically distributed throughout the Malay Peninsula (Hutchison and Tan 2009) where pockets of basalt outcrops are found in Segamat, Johor, and Beserah, Pahang. There is a quarry in Segamat that produces basalt dust of the size 
about $5 \mathrm{~mm}$ or less. The best ground basalt for agricultural use is the one with the size of $<1 \mathrm{~mm}$; anything bigger will take a long time to disintegrate and dissolve completely under field conditions (Shamshuddin et al. 2011; Anda et al. 2013). We now know that basalt is also found in Quiun Hills, Tawau, Sabah. Soils at this site are currently being used for growing cocoa.

It has been found that soil $\mathrm{pH}$ can be increased by ground basalt application (Anda et al. 2009, 2013; Shamshuddin and Kapok 2010). On dissolution, basalt not only increases soil $\mathrm{pH}$, but also supplies a significant amount of $\mathrm{Ca}, \mathrm{Mg}, \mathrm{K}, \mathrm{P}$, and $\mathrm{S}$ into the soil system (Gillman et al. 2002). The best agronomic practice is to apply basalt in combination with organic fertilizer (compost) that supplies some $\mathrm{N}$ to the growing cocoa in the field. Although basalt takes a long time to disintegrate and dissolve completely in soils (Shamshuddin et al. 2011; Anda et al. 2013), it gives a long-term ameliorative benefit to the cocoa plant. As soil $\mathrm{pH}$ increases, negative charges on the exchange complex of the variable-charged minerals increases (Shamshuddin and Ismail 1995). This helps retain most of the basic cations in the topsoil and hence, the productivity of Oxisols is further enhanced.

To prove that what has been said above is in order and defensible, a study has recently been conducted. The main objective of the study was to alleviate the infertility of an Oxisol from the Malaysian Cocoa Board Experimental Station, Temerloh, Malaysia, for cocoa cultivation using basalt in combination with compost. Other experimental plots in the research station have been limed adequately before planting cocoa. The research was conducted in a glasshouse at Universiti Putra Malaysia, Serdang. Thereafter, a field trial was conducted at the experimental station in Temerloh.

Basalt is an igneous rock containing mainly olivine, feldspars, pyroxenes, and amphiboles. In the presence of a sufficient amount of water, basalt disintegrates and dissolves, releasing $\mathrm{Ca}, \mathrm{Mg}, \mathrm{K}, \mathrm{P}$, and S into the soil system (Gillman et al. 2001, 2002). As such, basalt is a complete slow-released fertilizer without nitrogen. Of the minerals present in basalt, olivine is the most soluble in soils. The best basalt for the amelioration of Oxisols is the one that contains $\mathrm{Mg}$-olivine, called forsterite $\left(\mathrm{Mg}_{2} \mathrm{SiO}_{4}\right)$. Forsterite dissolves in soil solution, releasing $\mathrm{SiO}_{4}{ }^{4-}$ according to the following reaction:

$$
4 \mathrm{Mg}^{2+}+4 \mathrm{SiO}_{4}^{4-}+4 \mathrm{H}_{2} \mathrm{O} \rightarrow 4 \mathrm{Mg}^{2+}+\mathrm{Si}(\mathrm{OH})_{4}+4 \mathrm{OH}^{-}
$$

This reaction shows that a large amount of hydroxyl ions is released into the soil solution when $\mathrm{SiO}_{4}{ }^{4-}$ undergoes hydrolysis. In this reaction, silicic acid $\left[\mathrm{Si}(\mathrm{OH})_{4}\right]$ is concomitantly made available for uptake by the cocoa plant. It was found by Anda et al. (2013) that basalt application in the field increased soil solution Si significantly. The presence of a sufficient amount of $\mathrm{Si}$ in the plant system may possibly prevent the outbreak of certain cocoa diseases. Si is classified as a "beneficial nutrient" that can alleviate the problems of plants exposed to multiple stresses (Heckmam 2013). However, ground basalt takes a long time to dissolve completely even though under the condition of low pH (Shamshuddin et al. 2011; Anda et al. 2013). Nevertheless, basalt application is a good agronomic practice for the long-term ameliorative effects on the low productive Oxisols. 


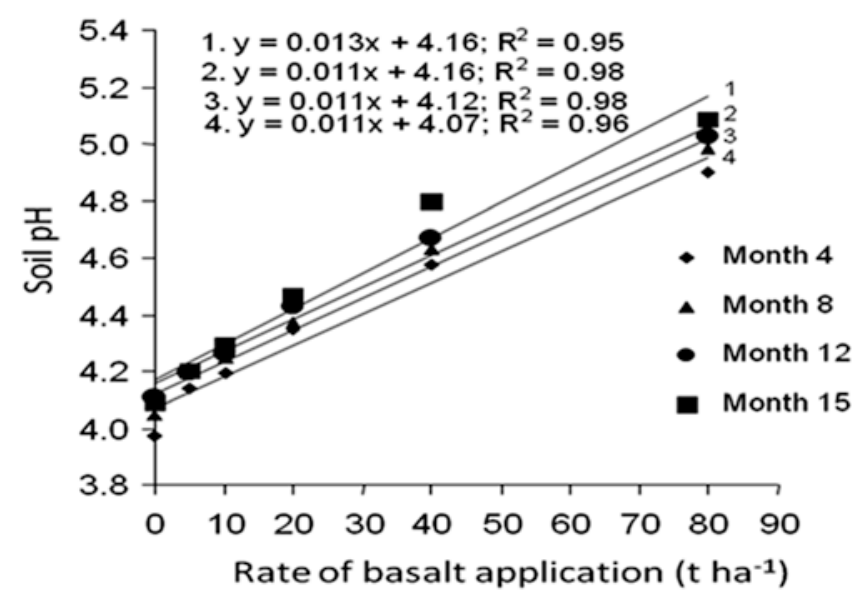

Fig. 1 Effect of basalt application on the $\mathrm{pH}$ of the topsoil of an Oxisol. Source: Shamshuddin and Anda (2008)

The result showed that soil $\mathrm{pH}$ increased linearly as basalt rate increased (Fig. 1). The basalt used in this glasshouse experiment was obtained from Australia, which had been studied in detail by Gillman et al. (2001) and (2002). In the current study, it was shown that soil $\mathrm{pH}$ increased after 15 months of basalt application (Anda et al. 2009), which is consistent with the study of Shamshuddin et al. (2011) and Anda et al. (2013).

Under the glasshouse condition, basalt application onto an Oxisol had lowered its pHo (Fig. 2). Likewise, in the field study, it was found that basalt application decreased pHo from 3.8 to 3.5 (Anda et al. 2013). It was also found that basalt applied in combination with compost had lowered the pHo of the soil even further. The lowering of $\mathrm{pHo}$ and increase in soil $\mathrm{pH}$ would have increased the CEC of the soil (Shamshuddin and Fauziah 2010a; Shamshuddin 2012). Increase in soil pH due to basalt application had reduced the soil solution $\mathrm{Al}$ and $\mathrm{Mn}$ concentration significantly and resulted in the healthy growth of cocoa plants in the field (Anda et al. 2013). These researchers concluded that after 24 months of basalt application in combination with compost, the growth of cocoa in terms of its height and girth diameter had increased significantly, which resulted in the early production of cocoa pods.

In a glasshouse experiment using cocoa as the test crop, soil solutions were extracted after 15 months of its growth (Table 1). The results showed that $\mathrm{Ca}, \mathrm{Mg}$, and $\mathrm{K}$ increased with increasing rate of basalt application. On the other hand, $\mathrm{Al}$ and Mn decreased, which means that basalt applied at the suitable rate was able to reduce the toxicity caused by the two acidic metals.

In the same experiment, it was observed that cocoa responded well to basalt application. For the control treatment, the dry matter weight was $709 \mathrm{~g} \mathrm{pot}^{-1}$ (Table 2). When basalt was applied at $10 \mathrm{tha}^{-1}$, the dry matter weight was increased 
Fig. 2 Effect of basalt application on the pHo of the topsoil of an Oxisol. Source: Anda et al. (2009)

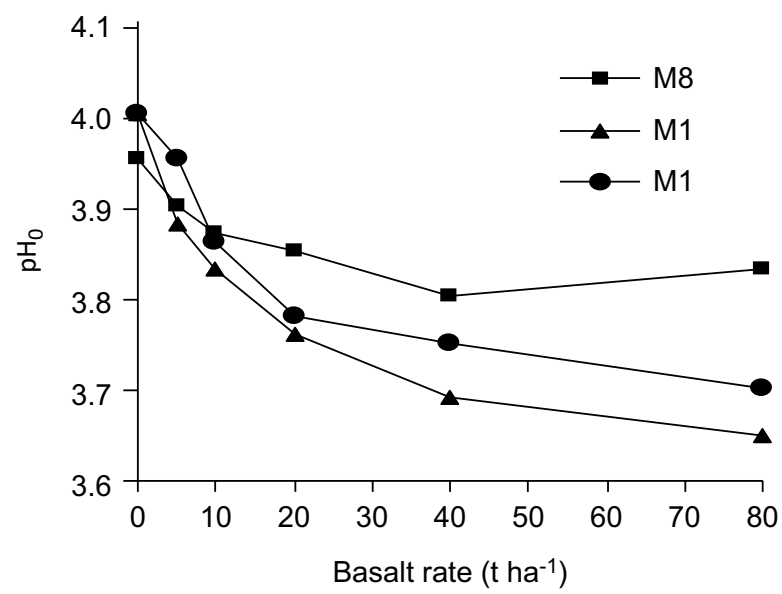

Table 1 The elemental composition of the soil solutions

\begin{tabular}{l|l|l|l|l|l}
\hline \multirow{2}{*}{ Basalt rate $\left(\mathrm{t} \mathrm{ha}^{-1}\right)$} & \multicolumn{4}{l}{} & Element \\
\cline { 2 - 7 } & $\mathrm{Ca}$ & $\mathrm{Mg}$ & $\mathrm{K}$ & $\mathrm{Al}$ & $\mathrm{Mn}$ \\
\cline { 2 - 7 } & $(\mu \mathrm{M})$ & \multicolumn{4}{l}{} \\
\hline 0 & $153 \mathrm{~b}$ & $66 \mathrm{c}$ & $41 \mathrm{c}$ & $16 \mathrm{a}$ & $29 \mathrm{a}$ \\
\hline 5 & $145 \mathrm{~b}$ & $139 \mathrm{c}$ & $36 \mathrm{c}$ & $13 \mathrm{~b}$ & $12 \mathrm{~b}$ \\
\hline 10 & $171 \mathrm{~b}$ & $153 \mathrm{c}$ & $39 \mathrm{c}$ & $6 \mathrm{c}$ & $9 \mathrm{c}$ \\
\hline 20 & $175 \mathrm{~b}$ & $317 \mathrm{~b}$ & $43 \mathrm{c}$ & $3 \mathrm{~cd}$ & $3 \mathrm{~d}$ \\
\hline 40 & $222 \mathrm{a}$ & $515 \mathrm{a}$ & $65 \mathrm{~b}$ & $2 \mathrm{~d}$ & $3 \mathrm{~d}$ \\
\hline 80 & $266 \mathrm{a}$ & $610 \mathrm{a}$ & $82 \mathrm{a}$ & $2 \mathrm{~d}$ & $1 \mathrm{~d}$ \\
\hline
\end{tabular}

Source: Shamshuddin et al. (2011)

Table 2 Dry matter weight (DMW) of cocoa as affected by basalt application

\begin{tabular}{l|l|l|l|l|l|l}
\hline Rate $\left(\mathrm{t} \mathrm{ha}^{-1}\right)$ & 0 & 5 & 10 & 20 & 40 & 80 \\
\hline DMW $\left(\mathrm{g} \mathrm{pot}^{-1}\right)$ & $709 \mathrm{c}$ & $742 \mathrm{c}$ & $846 \mathrm{~b}$ & $873 \mathrm{~b}$ & $899 \mathrm{ab}$ & $960 \mathrm{a}$ \\
\hline
\end{tabular}

Source: Shamshuddin et al. (2011)

to $846 \mathrm{~g} \mathrm{pot}^{-1}$. This clearly shows that basalt is a good soil amendment worth considering for application in cocoa plantations in Malaysia.

Data from the soil solution analyses of the field trial using the same soil as that of the glasshouse experiment were then studied in detail. Relative dry matter weight was plotted against Al concentration in the soil solution. The relationship between dry matter weight and soil solution $\mathrm{Al}$ is given in Fig. 3. The Al concentration corresponding to $90 \%$ relative dry matter weight is considered the critical level. From this figure, the critical $\mathrm{Al}$ level for cocoa of $4.7 \mu \mathrm{M}$ was then determined. Based on data presented in Table 1, it required about $20 \mathrm{t}_{\text {basalt }} \mathrm{ha}^{-1}$ to decrease the Al to this level of concentration. 
Fig. 3 Relationship between relative dry weight and soil solution $\mathrm{Al}$ concentration. Source: Shamshuddin et al. (2011)
Fig. 4 Relationship between dry matter weight and $\mathrm{Mn}$ concentration
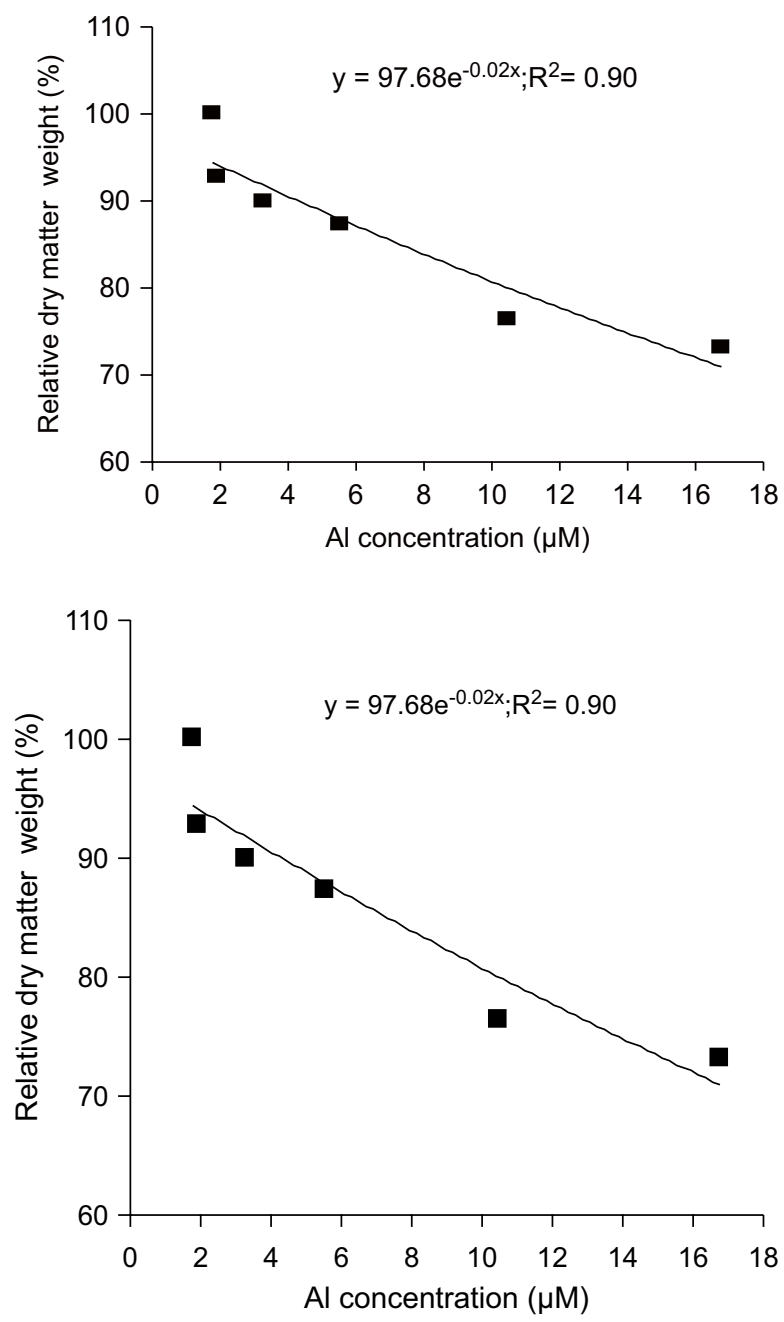

A similar graph was then plotted for Mn data and the graph obtained is given in Fig. 4. The critical Mn concentration estimated from this plot was 5.8 $\mu \mathrm{M}$. It shows that about $20 \mathrm{t}_{\text {basalt }} \mathrm{ha}^{-1}$ are needed to reduce $\mathrm{Mn}$ concentration to the level suitable for cocoa growth in the field. From glasshouse and field trials, it can be concluded that cocoa is indeed very sensitive to the presence of high $\mathrm{Al}$ and $\mathrm{Mn}$ concentration in the soil solution. For this reason, Oxisols can only be utilized for cocoa cultivation after they have been adequately limed. Alternatively, the soils can be ameliorated using ground basalt applied at the appropriate rate.

In rice, the uptake of $\mathrm{Si}$ in the form of silicic acid prevents the outbreak of rice blast disease (Abed-Ashtiani et al. 2012). It is likely that cocoa can also benefit from the presence of Si in its biomass (Heckmam 2013). A study in Indonesia by Wijaya 
et al. (2009) indicated that the pods on cocoa trees treated with Si were not attacked by pod borers, and may be attributed to their having Si, resulting in being harder than they otherwise were and therefore difficult to penetrate. The uptake of Si had improved cocoa growth significantly. Hence, it can be assumed that basalt application alleviates the problem of low fertility Oxisols, which finally provides the longterm benefits to growing cocoa in the plantations.

\section{Maintaining Organic Matter Level in Oxisols}

Organic matter in the Oxisols on which cocoa is planted should be maintained at the sufficient level of 2-3\%. When organic matter mineralizes, the NPK released from it are added into the soil system and are eventually available for the uptake by cocoa. This would, to some extent, reduce fertilizer application and therefore cut down the cost of production. In the glasshouse experiment using an Oxisols taken from the Malaysian Cocoa Board Experimental Station, Malaysia, compost was applied as a treatment either alone or in combination with basalt. It was found that application of compost in combination with basalt had improved cocoa growth by $37 \%$ (Anda et al. 2008b). This result is similar to that found by the field trial at the MCB Experimental Station (Anda et al. 2013). Compost being recalcitrant in nature due to the presence of a high amount of cellulose will have a long residence time in Oxisols and therefore has the potential to sustain $\mathrm{C}$ reserve in the soils.

\section{Effects of Fertilizer and/or Amendment Application on Soil Productivity}

In the planting hole, phosphate rock at the rate of $150 \mathrm{~kg}$ is usually applied to boost the growth of cocoa seedlings (MARDI 1990). For the mature cocoa in the field, the common fertilizers applied to supply the necessary nutrients (NPK) so as to sustain its growth are ammonium sulfate, phosphate rock, and muriate of potash, respectively. Occasionally, kieserite $\left(\mathrm{MgSO}_{4}\right)$ is applied to supply sufficient $\mathrm{Mg}$ to the cocoa plants.

It has been found in the long run that ammonium sulfate application on the soils of the tropics can result in the decrease of soil $\mathrm{pH}$. This phenomenon has been observed in the rubber plantations in India by Joseph (2012), which can also occur in the soils cropped to cocoa in Malaysia. However, the increase in soil acidity can be somewhat offset by the action of phosphate (Tessens and Zaharah 1983) and sulfate ions (Shamshuddin and Ismail 1995); the specific adsorption of the two anions on the surfaces of the oxides of Fe can, to a certain extent, increase soil $\mathrm{pH}$.

Another long-term effect of soil management for cocoa cultivation is the increase in $\mathrm{pH}$ due to GML or basalt application. The $\mathrm{pH}$ increase would result in the increase of CEC, attributed to the presence of a high amount of variable-charged minerals in 
Oxisols (Shamshuddin 2011, 2012). Basalt application also lowers pHo with the subsequent $\mathrm{pH}$ and CEC increase (Shamshuddin and Fauziah 2010b), further improving the productivity of the soils. The presence of extra $\mathrm{Ca}$ released by the dissolving GML or basalt can reduce the effects of Al stress (Alva et al. 1986). Cocoa is expected to perform better in the presence of high-solution Ca concentration than it otherwise is.

Adding gypsum into soils with a high amount of sesquioxides is good in itself. The $\mathrm{SO}_{4}{ }^{2-}$ thus released from the dissolution of gypsum is specifically adsorbed by the oxides, resulting in the release of hydroxyl ions that help increase the negative charge slightly (Shamshuddin and Ismail 1995). As mentioned above, the presence of extra $\mathrm{Ca}$ in the Oxisols due to gypsum application is able to reduce Al toxicity a bit (Alva et al. 1986). Under this condition cocoa is able to grow better than it otherwise is. It was found that by applying $4 \mathrm{tgypsum} \mathrm{ha}^{-1}$ on Oxisol, soil $\mathrm{pH}$ significantly increased from 4.18 to 4.54 (Shamshuddin and Ismail 1995). Thus, application of gypsum will further improve the productivity of the soil.

\section{Summary and Future Prospective}

In spite of their low fertility, Oxisols in Malaysia have been utilized for cocoa production in a big way. The acidity occurring in the Oxisols and the presence of toxic amounts of $\mathrm{Al}$ and $\mathrm{Mn}$ in the soil solution as well as the insufficient level of $\mathrm{Ca}$ and $\mathrm{Mg}$ can be alleviated by the application of ground magnesium limestone, basalt, and/or organic materials. Ca released by the dissolving lime or basalt can, to a certain extent, reduce Al toxicity. Cocoa is a fertilizer-demanding crop; hence, NPK fertilizers need to be adequately applied regularly. Long-term application of $\mathrm{N}$ fertilizer would increase soil acidity, but this will be offset by the release of hydroxyl ions as a result of phosphate and sulfate ions adsorption on the surfaces of the oxides of Fe present in the soils. The agronomic practices mentioned above should be adopted so as to sustain cocoa production on the Oxisols in Malaysia.

\section{References}

Abed-Ashtiani F, Kadir J, Selamat A, Ahmad Husni MH, Nasihi A (2012) Effects of foliar and root application of $\mathrm{Si}$ against rice blast fungus in MR 219 rice variety. Plant Pathol J 28(2):164-171

Alva AK, Asher CJ, Edwards DG (1986) The role of calcium in alleviating aluminum toxicity. Aust J Soil Res 37:375-383

Anda M, Shamshuddin J, Fauziah CI, Syed Omar SR (2008a) Mineralogy and factors controlling charge development of three Oxisols developed from different parent materials. Geoderma 143:153-167

Anda M, Syed Omar SR, Shamshuddin J, Fauziah CI (2008b) Changes in properties of composting rice husk and their effects on soil and cocoa growth. Commun Soil Sci Plant Anal 39: 2221-2249 
Anda M, Shamshuddin J, Fauziah CI, Syed Omar SR (2009) Dissolution of ground basalt and its effects on Oxisol chemical properties and cocoa growth. Soil Sci 174:264-271

Anda M, Shamshuddin J, Fauziah CI (2013) Increasing negative charge and nutrient contents of a highly weathered soil using basalt and rice husk to promote cocoa growth under field conditions. Soil Tillage Res 132:1-11

Gillman GP, Burkett DC, Coventry RJ (2001) A laboratory study of basalt dust to highly weathered soils: effect on soil chemistry. Aust J Soil Sci 39:799-811

Gillman GP, Burkett DC, Coventry RJ (2002) Amending highly weathered soils with finely ground basalt rock. Appl Geochem 17:987-1001

Heckmam J (2013) Silicon: a beneficial substance. Better Crops 97(4):14-16

Hutchison CS, Tan DNK (2009) Geology of Peninsular Malaysia. University of Malaya and Geological Society of Malaysia, Kuala Lumpur, Malaysia

Joseph M (2012) Acid soils of India under rubber cultivation and response of rubber to liming. In: Prakash NB et al (eds) Proceeding of the 8th international symposium on plant-soil interaction at low pH, October 18-22, 2012, Bengaluru, India, pp 254-255

Malaysian Agricultural Research \& Development Institute (MARDI) (1990) A guide for planting and processing cocoa. Berita Publishing, Kuala Lumpur

Rosilawati AK, Shamshuddin J, Fauziah CI (2014) Effects of incubating an acid sulfate soil treated with various liming materials under submerged and moist conditions on $\mathrm{pH}, \mathrm{Al}$ and Fe. Afr J Agric Res 9(1):94-112

Shamshuddin J (2011) Methods in soil mineralogy. UPM Press, Serdang, Malaysia

Shamshuddin J (2012) Charging phenomena in minerals. UPM Press, Serdang, Malaysia

Shamshuddin J, Anda M (2008) Charge properties of soils in Malaysia donated by kaolinite, gibbsite, goethite and hematite. Bull Geol Soc Malays 54:27-31

Shamshuddin J, Fauziah CI (2010a) Weathered tropical soils: the ultisols and oxisols. UPM Press, Serdang, Malaysia

Shamshuddin J, Fauziah CI (2010b) Alleviating acid soil infertility constraints using basalt, ground magnesium limestone and gypsum in a tropical environment. Malays J Soil Sci $14: 1-13$

Shamshuddin J, Ismail H (1995) Reactions of ground magnesium limestone and gypsum in soils with variable-charge minerals. Soil Sci Soc Am J 59:106-112

Shamshuddin J, Kapok JR (2010) Effect of ground basalt application on the chemical properties of an ultisol and oxisols in Malaysia. Pertanika J Trop Agric Sci 33:7-14

Shamshuddin J, Noordin WD (2011) Classification and management of highly weathered soils in Malaysia for production of plantation crops. In: Burcu E, Zkaraova G (eds) Principle, application and assessment in soil science. Intech, Croatia, pp 75-86

Shamshuddin J, Che Fauziah I, Sharifuddin HAH (1991) Effects of limestone and gypsum applications to a Malaysian ultisol on soils solution composition and yields of maize and groundnut. Plant Soil 134:45-52

Shamshuddin J, Syed Omar SR, Sharifuddin HAH (1997) Alleviating soil acidity in highly weathered tropical soils by limestone and gypsum application. Trends Soil Sci 2:205-215

Shamshuddin J, Sharifuddin HAH, Bell LC (1998) Longevity of magnesium limestone applied to an ultisol. Commun Soil Sci Plant Anal 29:1299-1313

Shamshuddin J, Fauziah CI, Bell LC (2009) Soil solution properties and yield of corn and groundnut grown on ultisols as affected by dolomitic limestone and gypsum applications. Malays J Soil Sci 13:1-12

Shamshuddin J, Shariduddin HAH, Che Fauziah I, Edwards DG, Bell LC (2010) Temporal changes in chemical properties of acid soil profiles treated with magnesium limestone and gypsum. Pertanika J Trop Agric Sci 33:277-295

Shamshuddin J, Anda M, Fauziah CI, Syed Omar SR (2011) Growth of cocoa planted on highly weathered soil as affected by application of basalt and/or compost. Commun Soil Sci Plant Anal 42:1-16

Soil Survey Staff (2010) Keys to soil taxonomy. United States Department of Agriculture, Washington, DC 
Tessens E, Shamshuddin J (1983) Quantitative relationship between mineralogy and properties of tropical soils. UPM Press, Serdang, Malaysia

Tessens E, Zaharah AB (1983) The residual influence of P-fertilizer application on soil pH values. Pédologie 32:367-368

Tessens E, Zauyah S (1982) Positive charge in oxisols. Soil Sci Soc Am J 46:1003-1006

Van Ranst E, Shamshuddin J, Baert G, Dzwowa PK (1998) Charge characteristics in relation to free iron and organic matter of soils from Bambouto Mountains, Cameron. Eur J Soil Sci 49: 243-252

Wijaya KA, Prawoto AA, Ihromi S (2009) Induction of cocoa natural resistance to cocoa pod borer by silica application. Pelita Perkebunan 25(3):184-198 